\title{
Improving influenza vaccination coverage at the University Medical Centre Ljubljana with workplace health promotion project
}

\author{
Nataša Dernovšček Hafner* and Tanja Udrih Lazar \\ Clinical Institute of Occupational, Traffic and Sports Medicine, University Medical Centre Ljubljana, Slovenia
}

\begin{abstract}
Seasonal influenza vaccination is one of the keys to preventing the spread of this disease. The seasonal influenza vaccination rate is very low for the general Slovenian population (the average rate from the 2015/16 season to the 2019/20 season is $4.3 \%$ ) and also for healthcare employees (between 2009 and 2019, the average vaccination rate among healthcare workers in Slovenia was 12.9\%), and it does not ensure sufficient community protection from the disease. At the beginning of the 2016/17 season, the University Medical Centre Ljubljana (UMCL) launched its first-ever occupational health promotion project with the slogan "I don't pass on the flu! I get vaccinated to protect myself and others." The goal of the project was to reach as many employees as possible and increase the general vaccination rate because those working in healthcare have a significantly greater risk of catching influenza than the rest of the working population. By being vaccinated, they protect not only themselves and their families against the disease, but also their patients. The project encouraged all employees to receive the free vaccination, especially those groups that had had lower vaccination rates over the past years. The support of the institution's executive staff and the heads of individual divisions was key to securing the required funds and suitable conditions for carrying out the project. Different communication tools were used in the project. The promotion strategy increased vaccination coverage at the UMCL from under $10.0 \%$ to $13.9 \%$ in $2016,20.9 \%$ in $2017,21.7 \%$ in 2018 , and $30.1 \%$ in 2019. Workplace health promotion can make a difference. The examples of good practice have made a substantial difference and will be taken into account in planning and organizing vaccination activities during future influenza seasons. This practical model can be used in other hospital settings as well.
\end{abstract}

Keywords: influenza vaccination, healthcare workers, workplace health promotion, motivational factors

\section{Izboljšanje precepljenosti proti sezonski gripi v UKC Ljubljana s projektom promocije zdravja pri delu}

\author{
Nataša Dernovšček Hafner* in Tanja Udrih Lazar \\ Klinični inštitut za medicino dela, prometa in športa, Univerzitetni klinični center Ljubljana
}

Povzetek: Cepljenje proti sezonski gripi je eden izmed najučinkovitejših preventivnih ukrepov pred širjenjem te nalezljive bolezni. Delež precepljenih v slovenski populaciji je zelo nizek (3,2 \% v sezoni 2016-2017), enako velja za zdravstvene delavce (9,1 \% v sezoni 2014-2015), kar ne zagotavlja zadostne kolektivne zaščite pred to boleznijo. V sezoni 2016-17 je bil v UKC Ljubljana prvič izveden projekt promocije zdravja pri delu s sloganom »Gripe ne prenašam! Zato se cepim! Tako ščitim sebe in druge«. Projekt je bil $\mathrm{v}$ usmerjen $\mathrm{v}$ boljšo osveščenost zdravstvenih delavcev in dvig deleža precepljenih, saj gre za poklicno skupino, ki je v primerjavi s preostalo delovno populacijo bolj izpostavljena in v precej večji meri tvega, da zboli za gripo. S cepljenjem zaposleni v zdravstvu ne zaščitijo le sebe in svojih družin, temveč tudi bolnike. Projekt je k brezplačnemu cepljenju spodbujal vse zaposlene, še zlasti pa skupine zaposlenih z najnižjim deležem precepljenosti. Podpora najvišjega vodstva ustanove ter vodij klinik in drugih organizacijskih enot je bila ključnega pomena za zagotovitev potrebnih sredstev in ustreznih pogojev za izvedbo projekta. Uporabljena komunikacijska sredstva so vključevala logotip, različna vizualna sporočila, uporabno darilo in priponko s sloganom projekta, ki so ju prejeli vsi zaposleni, ki so se cepili. S projektom promocije zdravja pri delu za preprečevanje širjenja sezonske gripe med zaposlenimi v UKC Ljubljana smo povečali delež precepljenih proti sezonski gripi iz 10,0 \% na 13,9 \% v letu 2016, 20,9 \% v letu 2017, 21,7 \% v 2018, in $30,1 \%$ v letu 2019. Projekt je nakazal številne možnosti za izboljšave pri načrtovanju in izvedbi cepitvenih aktivnosti v prihodnje. Primer dobre prakse lahko implementiramo tudi v druga bolnišnična okolja.

Ključne besede: cepljenje proti sezonski gripi, zdravstveni delavci, promocija zdravja pri delu, motivacijski dejavniki

\footnotetext{
"Naslov/Address: dr. Nataša Dernovšček Hafner, University Medical Centre Ljubljana, Clinical Institute of Occupational, Traffic and Sports Medicine, Grablovičeva 42, Slovenia, e-mail: natasa.dernovscekhafner@kclj.si
} 
Seasonal influenza vaccination is one of the most effective measures to prevent the spread of this contagious disease. Research shows that vaccinating healthy adults reduces the incidence of upper respiratory infection by approximately one-fourth and the number of general practitioner visits resulting from these illnesses by even one-half (Buxton Bridges et al., 2000; Nichol et al., 1995; Wilde et al., 1999). The effectiveness of the vaccine may differ by season, but the latest studies show that influenza vaccination reduces the risk of contracting this illness by 40 to $60 \%$ in the entire population and by 59 to $89 \%$ among healthy adults (Australian Technical Advisory Group on Immunisation [ATAGI], 2017; Centers for Disease Control and Prevention, 2020; Wilde et al., 1999;).

Influenza vaccination is especially important for healthcare workers because this occupational group is more exposed to and at a significantly higher risk of influenza than the rest of the working population (Kuster et al., 2011). By being vaccinated, healthcare workers protect not only themselves, their colleagues at work, and their families, but also their patients - that is, those that run the highest risk of severe disease, complications of their primary disease, and even death. In some places, vaccination of healthcare work-ers decreased mortality in long-term care by over $20 \%$ (Bull et al., 2007; Carman et al., 2000). In addition, it is not negligible that by being vaccinated healthcare workers can contribute to reduced sick leave due to influenza and thus a lower corporate cost of absenteeism (Colombo et al., 2006; Wilde et al., 1999).

In order to achieve such effects of vaccination, the Centers for Disease Control and Prevention (1986) recommended as early as three decades ago that $80 \%$ of healthcare workers be vaccinated, but this rate is only being achieved by a few health and social care institutions. The European Council recommends EU member states provide for a $75 \%$ vaccination rate among high-risk groups, including healthcare workers, but Kassianos (2015) believes that this could only be used as an initial milestone toward achieving $100 \%$ vaccination among healthcare workers without contraindications to influenza vaccination. In a European Centre for Disease Prevention and Control (ECDC) survey, which provided an update on seasonal influenza immunization policies in 2017/18, all 30 responding EU/EEA member states indicated that they had implemented national seasonal influenza vaccine recommendations for age groups, risk groups, and target groups during that season (European Centre for Disease Prevention and Control [ECDC], 2018).

Despite these recommendations and the fact that all EU countries recommend vaccination of healthcare workers, the actual vaccination rate in this target group remains relatively low. During the 2016/17 season, the lowest rate among the 12 countries monitoring these data was $15.6 \%$ (Italy) and the highest was $63.29 \%$ (Belgium), with the majority recording a rate of approximately $30.2 \%$ (European Centre for Disease Prevention and Control [ECDC], 2018). EU countries do not have a joint strategy for increasing the vaccination coverage of healthcare workers, whereas the US took a step further. Based on the 2010/11 data, when the vaccination rate of US healthcare workers was 55.8, in its Healthy People 2020 strategy the US government set the goal of gradually increasing this share to $90 \%$ (Office of Disease Prevention and Health Promotion, 2010).
The estimated overall influenza vaccination coverage among healthcare workers in the United States was $78.6 \%$ in the 2016/17 season, an increase of 15 percentage points since the 2010/11 season. As expected, the highest influenza vaccination coverage among healthcare workers continues to be reported in workplaces that require employees to be vaccinated (Black et al., 2017).

The vaccination rate among healthcare workers in Slovenia is also very low. Between 2009 and 2019, the average vaccination rate was $12.9 \%$ (Bosilj, 2020). This statistic is similar for the largest Slovenian health institution, the University Medical Centre Ljubljana (UMCL), which has over 8,000 employees. During the $2014 / 15$ season, this rate was $8.6 \%$ (Univerzitetni klinični center Ljubljana [UKCL], 2015).

This article presents a workplace health promotion project encouraging influenza vaccination at the largest hospital in Slovenia. The project goal was to increase the general vaccination rate of healthcare workers and, first and foremost, to encourage employee groups with the lowest vaccination rates to be vaccinated. This goal was targeted by increasing accessibility to vaccination, and by strengthening the support and communication campaign. To the best of our knowledge, this is the first such project in a hospital setting in Slovenia.

\section{Method}

During the 2016/17 season, the UMCL for the first time launched a workplace health promotion project encouraging influenza vaccination with the slogan "I don't pass on the flu! I get vaccinated to protect myself and others." Part of the project was an intense in-house social marketing campaign that focused on raising the awareness of available vaccination methods, doing away with erroneous beliefs and myths about vaccination, and spreading knowledge about the effectiveness of vaccination for disease prevention and its direct and indirect impacts. The project also focused on behavioral change and encouraged all employees to receive the free vaccination, but especially the employee groups with the lowest vaccination rate (i.e., those with a secondary or lower education). During the 2020/21 influenza season, the campaign is going to be carried out for the fifth year in a row.

\section{Planning the health promotion project}

The workplace health promotion project to prevent the spread of influenza was the result of cooperation between the Institute of Occupational, Traffic, and Sports Medicine and the Service for the Prevention of Hospital Infections using the data on employee vaccination rates from previous years, which had been falling persistently (23.2\% in $2008 / 09,21.6 \%$ in $2009 / 10,11.93 \%$ in $2010 / 11$, and only $8.6 \%$ during the $2014 / 15$ season) (UKCL, 2015). An especially low rate was observed among healthcare workers with a secondary or lower education. The project focused on increasing the accessibility of vaccination through an additional permanent vaccination station that would be accessible to workers in various medical center buildings and during various shifts, strengthening the support for 
vaccination among senior and middle management, and an intensive campaign via innovative communication channels and approaches.

When carrying out the project for the first time, we were especially interested in healthcare workers' main reason for being vaccinated, whether they were acquainted with the campaign, and how it affected their decision to be vaccinated. To this end, they received a dedicated Questionnaire on the Reasons and Motives for Influenza Vaccination during the 2016/17 season when they came for their vaccination. Due to the limited time available for completing the questionnaire, in addition to the basic demographic information (sex, age, and education), the questionnaire only included three multiple-choice questions about their main reason for being vaccinated, their main motive for deciding to be vaccinated, and whether they were acquainted with the campaign or how it affected their decision.

\section{Results}

The measures planned within the dedicated health promotion project were successfully implemented and the goal of increasing the vaccination coverage was also fully achieved. The promotion strategy increased vaccination coverage at the UMCL from under $10.0 \%$ to $13.9 \%$ in 2016 , $20.9 \%$ in $2017,21.7 \%$ in 2018 , and $30.1 \%$ in 2019 .

\section{Vaccination accessibility: creating a supportive environment}

Every year, the project dedicates special attention to marking the vaccination stations, which are dispersed across the major divisions, and improving the information on vaccination locations and schedules. Vaccination was carried out daily at 11 vaccination stations for five weeks following a schedule prepared in advance, and after that once a week at one vaccination station for another month.

During the 2017/18 influenza season, a permanent vaccination station (i.e., a dedicated area for administering the vaccine) was set up in the main lobby of the central building, which was extremely well visited. Seeking innovative approaches, a prefabricated structure with a permanent vaccination station was placed at a prominent location in the main lobby during the 2019/20 influenza season.

\section{Communication campaign}

The campaign's umbrella message was that employees should take responsibility and be vaccinated to protect themselves, their relatives, and their patients from the flu. This message was embedded in the umbrella slogan "I don't pass on the flu! I get vaccinated to protect myself and others," which called on every individual to act responsibly. The message was reinforced by the campaign's logo: a shield.

The campaign used various materials and communication tools conveying the relevant information and elaborations of the umbrella slogan:
- A brochure enclosed with every employee's pay slip featuring all the main information on influenza and vaccination, arguments against the widespread myths about influenza and vaccination, research data with evidence on the vaccine effectiveness, statements by a well-known infectious disease specialist in the role of a vaccination ambassador and a female patient that experienced severe influenza while pregnant, and so on;

- Posters of various sizes in prominent locations frequented by employees (main entrances, walls next to elevators, common areas at individual divisions, halls, kitchenettes, and so on) complemented by regularly updated weekly vaccination schedules;

- Stickers next to employee time clocks featuring a funny message for the employees, motivating them to be vaccinated;

- Marking the vaccination stations with posters and vaccination schedules and using stickers (stylized footprints) with the slogan "Stomp on the flu virus! Get vaccinated!" leading to these stations;

- Sending basic information on the vaccination and changes to the vaccination schedule via the intranet;

- A special website providing more information on the disease and vaccination, and news about how the vaccination campaign was progressing (e.g., that the executive staff was also among the first to be vaccinated);

- E-mails with reminders of where and when it was still possible to be vaccinated sent to all employees with an e-mail account when interest in receiving the vaccination was decreasing toward the end of the main part of the campaign.

\section{Incentives in the form of small gifts}

All the employees that received the vaccine also received a useful gift for the winter and a badge with the campaign slogan, so that they could also visually let other employees know that they had been vaccinated, encourage them to do the same, and thus become vaccination ambassadors themselves.

\section{Communicating with the executive staff and the management's role}

Before the activities started, the project was presented to the executive staff, the medical center expert council, and the nursing care expert committee, and later also to the healthcare workers in charge of hygiene, education, and quality control at various divisions. A personal letter was sent to all the heads of individual divisions and other organizational units, asking them to support the project and set an example for the employees and motivate them to be vaccinated.

The support of the institution's executive staff and the heads of individual divisions and other organizational units was key to securing the required funds and suitable conditions for carrying out the project. The heads of organizational units were especially encouraged to participate in the project and become vaccination ambassadors in their work environments, motivating employees to both be vaccinated themselves and take part in vaccination teams. 


\section{Communicating with specific employee groups}

Motivational interviews were also conducted with specific groups of employees, including lower-educated employees in the support services (e.g., patient escorts and cleaning staff), individuals that experienced severe influenza in a previous season despite having been vaccinated and that, according to the data on previous influenza seasons, were the least motivated to be vaccinated, and their superiors.

\section{Results of questionnaire analysis}

The questionnaire was completed by 823 employees at the UMCL, or $65 \%$ of those that received the vaccination in the $2016 / 17$ season $(69.2 \%$ women and $30.8 \%$ men). Just under one-half (45.9\%) belonged to the 25-40 age group and the 41-50 and 50+ age groups each accounted for an equal share of one-quarter. The share of healthcare workers younger than 25 was $6 \%$.

In terms of educational structure, $79.6 \%$ of respondents had at least a higher education degree, $12.9 \%$ had a 4 -year secondary degree, and the share of those that had completed primary or vocational school was $7.6 \%$.

Protecting themselves from influenza was the main motive for being vaccinated reported by $40.4 \%$ of respondents and $21.5 \%$ did it because vaccination had become a habit and they had been doing it for several years. Protecting family members from influenza was provided as the main motive by $9.6 \%$ of respondents and protecting patients by $8.2 \%$.

The predominating reason for being vaccinated was that vaccination was provided during work (34.1\%). The fact that it was provided for free encouraged $13.6 \%$ of respondents, whereas $41.6 \%$ did not select only one predominating reason, but circled several answers or reported other factors, such as chronic diseases, working in the influenza unit or with infected patients, and moral aspects (e.g., "because I think it's right," "because it makes sense," "to set an example"). Seeing other employees being vaccinated encouraged $9.3 \%$ of respondents, whereas seeing the management staff being vaccinated only encouraged a negligible share of respondents (i.e., under $1.5 \%$ ). The share of respondents that reported being acquainted with the "I don't pass on the flu" campaign that took place at the medical center in the fall of 2016 was $86.2 \%$. The campaign inspired one-third (30.2\%) to be vaccinated.

\section{Discussion}

Healthcare workers are a very diverse group in terms of age, expertise, education, primary work environment, work experience, nationality, and religion, which can all affect their attitude toward vaccination. According to a study by Doebbling et al. (as cited in Anikeeva et al., 2009), healthcare workers fifty years old or more with a higher socioeconomic status and more years of service at the same institution are more likely to accept influenza vaccination more positively than healthcare workers with a lower socioeconomic status and fewer years of service at the institution. It has been shown that the highest influenza vaccination coverage among healthcare personnel is achieved at workplaces that require employees to be vaccinated (Black at al., 2017). Healthcare personnel working in locations with lower influenza vaccination coverage reported that their employers did not require vaccination, make vaccination available onsite at no cost, or promote vaccination in any way (Black et al., 2017).

The survey conducted at the UMCL showed that employees with a higher education tend to be vaccinated more; they are generally better informed, show the highest motivation for being vaccinated, and are most likely also higher up on the socioeconomic ladder. The campaign took account of the healthcare workers' diversity and so the messages provided by the communication campaign were designed to reach as many employees at the medical center in varied ways.

The barriers to vaccination among healthcare workers are similar to those in the general population and have largely to do with views on vaccination and the disease itself (Dernovšček Hafner \& Udrih Lazar, 2017). Despite their greater exposure, healthcare workers estimate that their risk of infection is low and that they can avoid it by adhering to general hygiene recommendations and a healthy lifestyle. They believe that influenza is a mild disease, that complications are very rare or only typical of a small group of high-risk individuals, that they can develop immunity naturally through contact with their patients, that they can fall ill by being vaccinated, and that in general vaccination is ineffective and may cause adverse side effects (HeinrichMorrison et al., 2015; Kassianos, 2015; Marshall et al., 2010; Stuart, 2012). Other barriers include the fear of needles, the lack of information on vaccination opportunities, and lack of convenient access to vaccination in terms of time and place that would suit the individual (Heinrich-Morrison et al., 2015). The campaign conducted at the UMCL aimed to overcome these very obstacles and so its messages referred to facts about the vaccine effectiveness and side effects, the course of the disease and its consequences, and the advantages of vaccination for individuals, their families, their patients, and the organization.

Australian healthcare workers report that the most common motivational factor for being vaccinated against influenza is the desire to protect themselves (59 to $90 \%$ ), their friends and family (40 to $82 \%$ ), and their patients (over $70 \%$ ), followed by convenience of vaccination (accessibility in terms of time, place, and costs; 57 to $91 \%$ ). Reduction in sick leave and workplace guidelines were less frequently cited, but still significant motivational factors (Stuart, 2012). The results of the survey conducted among the employees at the UMCL agree with the findings of the Australian survey. The desire to protect themselves was also the most important motivational factor for vaccination at the UMCL, with convenient access to vaccination predominating among direct reasons. These results show that future campaigns should continue focusing on personal protection from influenza and investing in (even) greater access to vaccination. Access is the main barrier to more individuals being vaccinated against seasonal influenza (Grech \& Borg, 2020). Creating a support environment is one of the pillars of workplace health promotion programs that has a decisive impact on their effectiveness and, when combined 
with education and training, leads to gradual health beneficial changes in behavior (Udrih Lazar et al., 2016; World Health Organization, 1986). The support environment must ensure that health-promoting choices are always easier than the alternative.

The reasons for unsuccessful implementation of highquality programs in a healthcare setting are primarily the lack of cooperation among various occupational groups and rejecting change (Kumar, 2013). The management staff at the UMCL can primarily contribute to higher vaccination coverage by setting an example and deciding to be vaccinated themselves, and as vaccination campaign ambassadors. During the 2016/17 influenza season, this goal was achieved because the general manager and the medical director were among the first to be vaccinated. Because vaccination is completely voluntary, the management does not have any mechanisms at their disposal for rewarding or punishing employees for (not) being vaccinated. The survey results show that seeing other employees or the management staff being vaccinated was not among the most important motivational factors, but that does not mean that this does not have any effect on individuals' decision to be vaccinated. Research shows that an example set by the management staff can be very motivating (Hood et al., 2009). Employees that believe their superiors value their own health are more motivated to participate in health promotion programs (Franke et al., 2014; Skagert, 2010). Therefore, it makes sense to continue to enhance the support and example set by the management in further efforts to increase the influenza vaccination coverage at the UMCL. This year's vaccination season will be a special challenge because several strains of both the influenza and Covid-19 virus will be circling among the population and hence vaccination against influenza and motivating healthcare workers to be vaccinated will be more important than ever.

\section{Conclusion}

The workplace health promotion project to prevent the spread of seasonal influenza among the employees at the UMCL already attained its goal of a $100 \%$ increase in vaccination coverage in the $2017 / 18$ season, with the result being further improved in the following two seasons. The evaluation survey among those that were vaccinated also showed that the vaccination campaign had a satisfactory impact on this group, motivating one-third of respondents to be vaccinated. Encouraging even more employees to be vaccinated remains the main goal of the project in the future. The project has revealed many opportunities for improvement in planning future activities, including additionally increasing access to vaccination in terms of time and place; this can largely be achieved by retaining the central location of the permanent vaccination station, establishing additional vaccination teams that would administer the vaccine across the basic units, and enhancing specific approaches to motivate groups with the lowest vaccination coverage.

\section{References}

Anikeeva, O., Braunack-Mayer, A., \& Rogers, W. (2009). Requiring influenza vaccination for health care workers. American Journal of Public Health, 99(1), 24-29.

Australian Technical Advisory Group on Immunisation (2017). The Australian Immunisation Handbook (10th ed). Australian Government Department of Health. Retrieved August 10, 2020, from https://immunisationhandbook. health.gov.au/vaccine-preventable-diseases/influenza-flu

Black, C. L., Yue, X., Ball, S. W., Fink, R., de Perio, M. A., Scott Laney, A., Williams, W. W., Lindley, M. C., Graitcer, S. B., Lu, P.-J., Devlin, R., \& Greby, S. M. (2017). Influenza vaccination coverage among health care personnel - United States, 2016-17 influenza season. MMWR, Morbidity and mortality weekly report, 66(38), 1009-1015.

Bosilj, M. (2020). Analiza precepljenosti zdravstvenih delavcev proti gripi $v$ Sloveniji med leti 2009 in 2019 [Analysis of flu vaccination rate among healthcare workers in Slovenia between the years 2009 and 2019] [Master's thesis, University of Maribor, Faculty of Health Sciences]. Digital Library of University of Maribor. https://dk.um.si/IzpisGradiva.php?id=76454

Bull, A. L., Bennet, N., Pitcher, H. C., Russo, P. L., \& Richards, M. J. (2007). Influenza vaccine coverage among health care workers in Victorian public hospitals. The Medical Journal of Australia, 186(4), 185-186.

Buxton Bridges, C., Thompson, W. W., Meltzer, M. I., Reeve, G. R., Talamonti, W. J., Cox, N. J., Lilac H. A., Hall, H., Klimov, A., \& Fukuda, K. (2000). Effectiveness and cost-benefit of influenza vaccination of healthy working adults: A randomized controlled trial. JAMA, 284(13), 1655-1663.

Carman, W. F., Elder, A. G., Wallace, L. A., McAulay, K., Walker, A., Murray, G. D., \& Stott, D. J. (2000). Effects of influenza vaccination of health-care workers on mortality of elderly people in long-term care: A randomized controlled trial. Lancet, 355(14), 889-893.

Centers for Disease Control and Prevention. (1986). Recommendations for prevention and control of influenza: Recommendations of the Immunization Practices Advisory Committee. Centers for Disease Control, Department of Health and Human Services. Annals of Internal Medicine, 105(3), 399-404.

Centers for Disease Control and Prevention. (2020, January 3). Vaccine effectiveness: How well do the flu vaccines work? Questions \& answers. Retrieved August 10, 2020, from https://www.cdc.gov/flu/vaccines-work/ vaccineeffect.htm

Colombo, G. L., Ferro, A., Vinci, M., Zordan, M., \& Serra, G. (2006). Cost-benefit analysis of influenza vaccination in a public healthcare unit. Therapeutics and Clinical Risk Management, 2(2), 219-226. 
Dernovšček Hafner, N., \& Udrih Lazar, T. (2017). Cepljenje proti gripi $v$ UKC Ljubljana: Poročilo o raziskavi 2017 [Influenza vaccination at the University Medical Center Ljubljana: Research report 2017]. University Medical Centre Ljubljana, Institute of Occupational, Traffic, and Sports Medicine. https://www.cilizadelo.si/e_files/ content/Porocilo_o_cepljenju_proti_gripi.pdf

European Centre for Disease Prevention and Control. (2018). Seasonal influenza vaccination and antiviral use in EU/EEA Member States - Overview of vaccine recommendations for 2017-2018 and vaccination coverage rates for 2015-2016 and 2016-2017 influenza seasons. https://www.ecdc.europa.eu/sites/default/files/ documents/seasonal-influenza-antiviral-use-2018.pdf

Franke, F., Felfe, J., \& Pundt, A. (2014). The impact of healthoriented leadership on follower health: Development and test of a new instrument measuring health-promoting leadership. German Journal of Research in Human Resource Management, 28(1-2), 139-161.

Grech, V., \& Borg, M. (2020). Influenza vaccination in the COVID-19 era. Early Human Development, 148, Article 105116.

Heinrich-Morrison, K., McLellan, S., McGinnes, U., Carroll, B., Watson, K., Bass, P., Worth, L. J, \& Cheng, A. C. (2015). An effective strategy for influenza vaccination of healthcare workers in Australia: Experience at a large health service without a mandatory policy. $B M C$ Infectious Diseases, 15(42).

Hood, J., Smith, A., \& Childre, F. (2009). Developing a "best practice" influenza vaccination program for health care workers - An evidence-based, leadership-modeled program. Official Journal of the American Association of Occupational Health Nurses, 57(8), 308-312.

Kassianos, G. (2015). Willingness of European healthcare workers to undergo vaccination against seasonal influenza: Current situation and suggestions for improvement. Drugs in Context, 4, Article 212268.

Kumar, R. D. C. (2013). Leadership in healthcare. Anaesthesia and Intensive Care Medicine, 14(1), 39-41.

Kuster, S. P., Shah, P. S., Coleman, B. L., Lam, P-P., Tong A., Wormsbecker, A., \& McGeer, A. (2011). Incidence of influenza in healthy adults and healthcare workers: A systematic review and meta-analysis. PLoS One, 6(10), Article e26239.

Marshall, R. J., Tetu-Mouradjian, L. M., \& Fulton, J. P. (2010). Increasing annual influenza vaccinations among healthcare workers in Rhode Island: A social marketing approach. Medicine and health, Rhode Island, 93(9), 271-278.

Nichol, K. L., Lind, A., Margolis, K. L., Murdoch, M., McFadden, R., Hauge, M., Magnan, S., \& Drake, M. (1995). The effectiveness of vaccination against influenza in healthy, working adults. The New England Journal of Medicine, 333(14), 889-893.

Office of Disease Prevention and Health Promotion. (2010). Immunization and Infectious Diseases. Healthy People 2020. Retrieved August 10, 2021, from https:// www.healthypeople.gov/2020/topics-objectives/topic/ immunization-and-infectious-diseases
Skagert, K. (2010). Leadership in human service organisations: Conceptions, strategies and preconditions to promote and maintain health at work: Doctoral Thesis [Unpublished manuscript]. Department of Public Health and Community Medicine, University of Gothenburg.

Stuart, M. J. (2012). Review of strategies to enhance the uptake of seasonal influenza vaccination by Australian healthcare workers. Communicable diseases intelligence, 36(3), E268-E276.

Udrih Lazar, T., Stergar, E., \& Zabukovec V. (2016). Zdravje in promocija zdravja pri delu [Health and health promotion at work]. In D. Miklič Milek \& T. Udrih Lazar (Eds.), Čili za delo: Učbenik za promocijo zdravja pri delu (pp. 34-74). University Medical Centre Ljubljana, Institute of Occupational, Traffic, and Sports Medicine.

Univerzitetni klinični center Ljubljana. (2015, February). Poročilo o izvajanju letnega plana aktivnosti na področju preprečevanja in obvladovanja bolnišničnih okužb za leto 2014 in plan aktivnosti za leto 2015 [Report on the implementation of the annual plan of activities in the field of prevention and control of nosocomial infections for 2014 and the plan of activities for 2015] [Unpublished report].

Wilde, J. A., McMillan, J. A., Serwint, J., Butta, J., O'Riordan, M. A., \& Steinhoff M. C. (1999). Effectiveness of influenza vaccine in health care professionals: A randomized trial. Jama, 281(10), 908-913.

World Health Organization (1986, November 21). The Ottawa Charter for Health Promotion. https://www.who.int/ healthpromotion/conferences/previous/ottawa/en/ 